Journal of Telenursing (JOTING)

Volume 2, Nomor 2, Desember 2020

e-ISSN: 2684-8988

p-ISSN: 2684-8996

DOI: https://doi.org/10.31539/joting.v2i2.1528

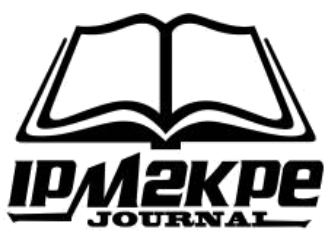

\title{
KOPING RELIGIUS PADA KELOMPOK PENDERITA HIV/AIDS
}

\author{
Muhammad Bagus Andrianto ${ }^{1}$, Asih Dewi Setyawati², Muhammad Muin ${ }^{3}$, \\ Fery Agusman Motuho Mendrofa ${ }^{4}$ \\ Universitas Muhammadiyah Bengkulu ${ }^{1,2}$ \\ Universitas Diponegoro ${ }^{3}$ \\ Sekolah Tinggi Ilmu Kesehatan Karya Husada ${ }^{4}$ \\ bagus@umb.ac.id ${ }^{1}$
}

\begin{abstract}
ABSTRAK
Tujuan penelitian ini adalah untuk mengetahui gambaran koping religius pada penderita HIV/AIDS. Metode dalam penelitian ini menggunakan penelitian deskriptif. Hasil penelitian dari total 69 didapatkan data koping religius penderita HIV/AIDS sedang sebesar 42 responden $(60,9 \%)$. Simpulan, perlunya dukungan dan dorongan penderita HIV/AIDS dalam meningkatkan koping yang adaptif, sehingga dapat mengelola penyakit yang dialaminya.
\end{abstract}

Kata Kunci: HIV/AIDS, Koping Religius

\section{ABSTRACT}

The purpose of this study was to see a picture of people living with religious HIV / AIDS. The method in this research is using descriptive analysis. From a total of 69, the results of the study obtained moderate religious data on people living with HIV / AIDS of 42 respondents (60.9\%). In conclusion, the need for support and guidance for HIV / AIDS in increasing adaptive coping can manage the disease it is experiencing.

Keywords: HIV / AIDS, Religious Coping

PENDAHULUAN

HIV/AIDS adalah salah satu penyakit kronis dan penyakit menular mematikan di dunia yang kemudian menjadi wabah internasional. AIDS (Acquired Immuno Deficiency Syndrome) merupakan kumpulan gejala penyakit yang disebabkan oleh virus HIV (Human Immunodeficiency Virus) yang dapat menular dan mematikan. Virus tersebut menyerang sistem kekebalan tubuh manusia dan perkembangannya bertahan di dalam tubuh hingga jangka waktu 5-10 tahun dan individu yang terinfeksi virus tersebut akan mengalami penurunan daya tahan tubuh yang ekstrim sehingga mudah terjangkit penyakit-penyakit infeksi dan bisa menyebabkan kematian (Widyarsono, 2013).

Jumlah pederita HIV/AIDS Pada tahun 2015, tercatat ada sekitar 36,7 juta jiwa terinfeksi HIV dan 1,1 juta kematian akibat AIDS di seluruh dunia. Kawasan dengan angka kasus HIV dan AIDS terbanyak di dunia adalah kawasan Afrika.Dari jumlah penderita tersebut tergolong usia dari 20 tahun sampai 40 tahun. Penderita HIV/AIDS merupakan kalangan laki-laki (World Health Organization 2016). 
Sedangkan di Indonesia jumlah kumulatif penderita HIV/AIDS pada umur $>15$ tahun pada tahun 2015 untuk jumlah HIV baru yaitu sebanyak 30.935 orang, pada tahun 2016 sebanyak 41.250 orang, pada tahun 2017 sebanyak 48.300 orang. Sedangkan kasus baru AIDS pada tahun 2015 yaitu 9.215 orang, pada tahun 2016 sebanyak 10.146 orang, pada tahun 2017 sebanyak 9.280 orang, maka dijumlahkan keseluruhan penderita HIV/AIDS pada tahun 2017 sebanyak 628.492 orang dengan jumlah infeksi baru sebanyak 46.357 orang dan kematian sebanyak 40.468 orang. Dari tahun ke tahun penderita HIV/AIDS cenderung meningkat, untuk golongan penderita HIV/AIDS cenderung banyak dari laki-laki dari pada permpuan. Di indonesia penderita HIV/AIDS terbanyak di DKI Jakarta terus diikuti Jawa Timur, Papua, Jawa Barat, Bali, Sumatra Utara, Jawa Tengah, Kalimantan Barat, Kepulauan Riau, dan Selawisi selatan (Kemenkes, 2017).

Penyakit AIDS bisa menyerang siapa saja dan jika sudah positif trinfeksi maka penderita ini akan menjadi orang yang menularkan virus ini seumur hidup mereka (Padila, 2012). Penyakit AIDS bisa menyerang siapa saja dan jika sudah positif trinfeksi maka penderita ini akan menjadi orang yang menularkan virus ini seumur hidup mereka. Berbagai macam reaksi yang bisa dilihat dari penderita yang sudah positif terkena HIV/AIDS ini, antara lain perasaan marah, ketakutan yang berlebihan, histeris dan biasanya tidak bisa menerima kenyataan tentang penyakit yang diderita saat ini. Pasien juga akan merasa dirinya tidak layak lagi untuk hidup dan rentan melakukan tindakan bunuh diri serta menjadi lebih tertutup dari orang lain dan lingkungan (Muslimah, 2013).

Orang yang sudah positif terinfeksi HIV/AIDS akan mengalami perubahan baik fisik, psikologis dan sosial. Perubahan fisik yang terjadi biasanya penderita akan mengalami penurunan daya tahan tubuh sehingga akan rentan terserang oleh berbagai penyakit, dering mengalami demam dan mudah lelah (Surahma, 2012). Masalah sosial yang sering dialami penderita HIV antara lain stigma dari lingkungan sosial, banyak yang berangaapan bahwa pwnyakit ini adalah penyakit yang mematikan yang bisa menular melalui kontak langsung seperti berjabat tangan atau tidak sengaja bersentuhan dengan mereka. Hal ini menjadi penyebab pasien HIV sering dikucilkan dan mendapatkan tindakan diskriminatif dari masyarakat (Widyarsono, 2013).

Orang dengan HIV AIDS (ODHA) sering dihadapkan pada kondisi yang rumit apakah harus mengungkapkan apa yang dialami atau menyembunyikan kondisi penyakit. Menyembunyikan kondisi penyakit dapat mengakibatkan penderitaan batin yang dirasakan sangat menyiksa karena beban menjaga rahasia (Rouleau et al., 2012). Di sisi lain, mengungkapkan kondisi penyakit juga dapat menimbulkan permasalahan seperti penolakan (Chaudoir et al., 2011).

Stigma dan diskriminasi pada ODHA akan menjadi stress bagi penderitanya. Stress memiliki dampak yang kurang baik bagi kesehatan orang dengan HIV/AIDS, dalam upaya menangani stress, seorang individu membutuhkan koping stress yang tepat (Indriani \& Fauziah, 2017).

Faktor-faktor yang mempengaruhi spiritualitas meliputi konteks budaya, keluarga, tingkat perkembangan, dan status kesehatan. Pengaruh keluarga dan lingkungan mempengaruhi dalam penilaian keyakinan spiritualitas. Status kesehatan juga bisa berdampak pada kepercayaan spiritualitas dan sebaliknya. Misalnya, saat sakit parah, banyak orang beralih ke agama untuk mendapatkan dukungan. Dalam beberapa kasus, sistem kepercayaan seseorang mungkin akan mempengaruhi pengobatan (Lubis et al., 2016). 
Penderita dengan coping religius positif dalam meningkatkan spiritualitas penderita HIV/AIDS dapat membuat seseorang dapat bersosialisasi, psikologis lebih baik dan perkembangan penyakit menjadi lambat. Sedangkan penderita dengan koping religus negatif dapat memunculkan sikap penolakan terhadap terapi ARV, perasaan mendalam hukuman dari Tuhan dan penyimpangan jati diri remaja (Hulu \& Siregar, 2018).

\section{METODE PENELITIAN}

Penelitian ini menggunakan desain penelitian deskriptif analitik dengan pendekatan cross sectional yaitu dengan menggambarkan variabel-variabel dari penelitian yang kemudian di interpretasikan. Penelitian dilakukan secara observasional deskriptif. Penelitian ini dilakukan di Temanggung Jawa Tengah. Pengambilan sampel dalam penelitian ini menggunakan consecutive sampling sebanyak 69 responden. Instrumen yang di gunakan adalah dengan kuesioner yang berisi daftar pertanyaan untuk menilai karakteristik responden, spiritualitas dan juga koping religius.

Analisis univariat untuk menggambarkan karakteristik responden meliputi usia, jenis kelamin, pekerjaan, agama, pendidikan terakhir, penghasilan dan karakteristik praktik keagamaan. Analisis bivariat menggunakan uji chi-square.

\section{.HASIL PENELITIAN}

Analisi Univariat

Tabel. 1

Distribusi Karakteristik Responden Berdasarkan Usia, Jenis Kelamin, Tingkat Pendidikan, Pekerjaan dan Penghasilan $(n=69)$

\begin{tabular}{lcc}
\hline Karakteristik & Frekuensi & Persentase (\%) \\
\hline Usia & 12 & \\
$17-25$ & 22 & 17.4 \\
$26-35$ & 26 & 31.9 \\
$36-45$ & 9 & 37.7 \\
46-55 & & 13 \\
\hline Jenis Kelamin & 32 & \\
Pria & 37 & 46.4 \\
Wanita & & 53.6 \\
Tingkat Pendidikan & 1 & \\
Tidak Sekolah & 11 & 2.2 \\
SD & 18 & 15.9 \\
SMP & 33 & 26.1 \\
SMA & 3 & 47.8 \\
D3 & 3 & 4.3 \\
S1 & & 3.6 \\
\hline Pekerjaan & 16 & \\
Tidak bekerja & 2 & 23.2 \\
Petani & 41 & 2.9 \\
Swasta & 10 & 59.4 \\
Lainya & & 14.5 \\
Penghasilan & 55 & \\
< Rp. 1.500.000. & 14 & 79.7 \\
Z Rp. 1.500.000. & & 20.3 \\
\hline
\end{tabular}


Berdasarkan tabel 1 menunjukkan bahwa dari 69 responden penderita HIV/AIDS sebagian besar responden adalah wanita 37 orang (32,6\%), sebagian besar memiliki umur antara 36-45 tahun sebesar 26 orang $(37,7 \%)$, dengan tingkat pendidikan lulusan SMA 33 orang $(47,8 \%)$, sedangkan pekerjaan responden adalah swastas sebesar 41 orang $(59,4 \%)$, berkaitan dengan pendapatan responden per bulan kurang dari $<\mathrm{Rp}$ 1.500.000,- sebesar 55 orang $(79.7 \%)$.

Tabel. 2

Distribusi Frekuensi Koping Religius (n=69)

\begin{tabular}{ccc}
\hline Variabel Koping Religus & Frekuensi & Presentase $(\%)$ \\
\hline Koping Religius Kurang & 16 & 23.2 \\
Koping Religus cukup & 42 & 60.9 \\
Koping Religus baik & 11 & 15.9 \\
\hline Total & 69 & 100 \\
\hline
\end{tabular}

Berdasarkan tabel 2 menunjukkan bahwa dari 69 responden pendeita HIV/AIDS memiliki koping sebanyak $16(23.2 \%)$ Responden memiliki koping religius rendah, koping religius sedang sebanyak $42(60.9 \%)$ responden dan koping religius tinggi sebesar $11(15.9 \%)$ responden.

\section{PEMBAHASAN}

Hasil penelitian menunjukkan bahwa gambaran koping religius penderita HIV/AIDS memiliki koping religius cukup. Penelitian yang dilakukan oleh Hidayah (2014) pasien HIV/AIDS akan bisa menerima kenyataan mengenai penyakitnya ketika banyak orang memberikan dukungan sosial kepada mereka. Selain dukungan sosial, strategi koping juga sangat membantu untuk meningkatkan kekuatan, pemulihan sumber daya manusia, fungsi sosial dan mengurangi stress dan depresi pada pasien.

Strategi koping religius merupakan usaha mengatasi masalah dengan cara melakukan tindakan ritual keagamaan, misalnya sembahyang, berdoa, atau pergi ke rumah ibadah. Strategi koping ini didasari oleh adanya keyakinan bahwa Tuhan akan membantu seseorang yang mempunyai masalah (Khoiroh, 2013).

Hasil penelitian Krisdayanti \& Hutasoit (2019) menunjukkan bahwa coping strategis sangat mempengaruhi kesehatan mental dan membantu meningkatkan kualitas hidup penderita HIV/AIDS positif. Coping strategy merupakan koping yang digunakan individu secara sadar dan terarah dalam mengatasi sakit atau stresor yang dihadapinya. Terbentuknya mekanisme koping bisa diperoleh melalui proses belajar dalam pengertian yang luas dan relaksasi. Apabila individu mempunyai mekanisme koping yang efektif dalam menghadapi stresor, maka stresor tidak akan menimbulkan stres yang berakibat kesakitan (disease), tetapi stresor justru menjadi stimulan yang mendatangkan wellness dan prestasi (Norcini, 2015).

Religiusitas merupakan nilai yang mempengaruhi seseorang dalam berpikir, berperilaku dan berpenampilan. Salah satu dimensi religiusitas yang mengatur individu dalam beperilaku maupun berpenampilan adalah dimensi pengalaman atau akhlak. Akhlak berfungsi untuk mengetahui batas antara yang baik dengan yang buruk dan dapat menempatkan sesuatu pada tempatnya yaitu menempatkan sesuatu pada proposi yang sebenarnya. Religiusitas islam tidak hanya sebatas agama yang memerintahkan pemeluknya untuk menjalankan ritulistik menyembah Tuhan, akan tetapi agama yang benar benar mempunyai ajaran yang lengkap yang mengatur aspek kehifupan manusia baik aspek ibadah, social, hokum, politik, ekonomi, akhlak manusia untuk mencapai 
kebahagiaan dunia sampai akhirat.

Religiusitas adalah suatu tindakan formal seseorang yang berkaitan dengan aktivitas beragamanya sebagai bentuk komitmen diri terhadap agamanya yang diekspresikan (Trevino et al., 2010). Hasil penelitian menunjukkan bahwa aspek religisiutas dalam hal praktik ibadat dan penghayatan terhadap beragama serta intelektual pengetahuan ajaran agama yang diemban masih rendah. Penghayatan terhadap beragama dan pengetahuan terhadap agama masih rendah ditunjukkan dengan ungkapan informan ke-1, informan ke-2, dan informan ke-4 Adapun ungkapan yang muncul diantaranya (Aisyah et al., 2020).

Salah satu aspek religiusitas islam yaitu dimensi keyakinan tentang kitab Allah yaitu Al-Quran. Umat islam tidak hanya sebatas yakin terhadap kebenaran Al-Quran sebagai wahyu dari Allah, akan tetapi bagaiman berfikir, memahani isi dan kandungan ayat yang ada di dalamnya. Sebagai contoh salahs atu akhlak islam adalah kasih sayang meliputi ampunan dan ihsan. kasih sayang itu bukan hanya empati saja akan tetapi merupakan perwujudan perilaku di luar yang akan tampak di dalam jiwa. Contohnya adalah memberikan maaf kepda orang khilaf, memberikan ampunan orang yang salah.

Religiusitas membentuk pribadi seseorang dalam berperilaku seperti kejujuran, empati, toleran, kasih sayang, semangat. Praktik kegamaan termasuk dalam dimensi religiusitas yang mengajarkan tentang moral dan iman. Hasil penelitian praktik agama menunjukkan cukup baik dengan koping religius dpat disimpulkan bahwa agama menjadi kebutuhan yang paling dibutuhkan bagi penderita HIV/AIDS. Agama bagi Penderita HIV/AIDS dapat menjadi keyakinan untuk berkomunikasi dengan sang pencipta untuk memohon pengampunan dan pertolongan. Dengan keyakinan beragama tersebut mereka dapat meredakan konflik batin serta mendapatkan kedamaian.

Penelitian tentang kebutuhan spiritual meliputi: kebutuhan religi atau keagamaan, eksistensi diri, kebutuhan mendapatkan kedamaian, serta kebutuhan untuk memberi. Kebutuhan agama/religi menjadi yang sering menonjol. Akan tetapi, individu memiliki perbedaan kebutuhan dalam aspek maupun tingkat kebutuhannya masing-masing.

Peneliti menemukan mayoritas penderita HII/AIDS berada pada usia dewasa (3645 tahun), pada usia tersebut mayoritas menyadari bahwa hidupnya harus banyak mendekatkan diri dengan Tuhan. Hal ini diperkuat bahwa spiritualitas bagi pasien dapat berarti penerimaan dan kepasrahan kepada Tuhan namun disertai dengan usaha dan ikhtiar untuk mendapatkan kesembuhan. Salah satu caranya adalah dengan mendekatkan diri dan meningkatkan taqwa kepada Allah. Kebutuhan spiritual dari dimensi religi yang dianggap amat sangat dibutuhkan pada pasien adalah dengan praktik keagamaan.

Praktik agama adalah salah satu bagian dari metode koping religius dengan Tuhan. Koping religius dapat membantu manusia dalam menurunkan kecemasan, kegelisahan, dan ketegangan yang membuat mereka tidak bisa menyesuaikan diri dengan lingkungannya.38 Metode koping yang digunakan pada penderita HIV/AIDS dalam menghadapi penyakitnya adalah koping religius dengan membuat hubungan dengan Allah, yaitu melakukan perubahan besar pada diri sendiri setelah menderita penyakit. Akan tetapi penderita HIV/AIDS dalam menghadapi penyakitnya kurang mengambil hikmah di balik penyakit yang di alaminya.

Menurut Anggraini \& Suci (2014) pada umumnya seseorang yang memiliki keyakinan pada agama apabila mengalami suatu situasi yang sulit maka individu tersebut akan melibatkan unsur-unsur keagamaan dalam mengatasi setiap permasalahan yang dialaminya. 
Hasil penelitian menunjukkan bahwa seluruh informan memiliki kecenderungan menggunakan tehnik penyelesaian masalah dengan melibatkan Tuhan disaat semua cara penyelesaian masalah tidak membantu. Ketika seseorang mencari kontrol melalui inisiatif dirinya dengan meminta bantuan orang lain terlebih dahulu atau mencari cara lain. Tindakan seperti itu merupakan bentuk koping religius negatif dimana jalan melalui pertolongan agama dijadikan sebagai jalan terakhir bukan jalan utama (Aisyah et al., 2020).

Penelitian yang dilakukan Tanjung \& Devi (2016) menjelaskan bahwa karakteristik distress spiritual pada Orang Dengan HIV/AIDS (ODHA) paling banyak pada aspek hubungan dengan Tuhan. Karakteristik distress spiritual berdasarkan aspek hubungan dengan diri sendiri paling banyak berada pada karakteristik kurangnya makna hidup. Karakteristik distress spiritual berdasarkan aspek hubungan dengan orang lain paling banyak berada pada karakteristik mengungkapkan rasa terasing. Karakteristik distress spiritual berdasarkan aspek hubungan dengan seni, musik, literatur, alam paling banyak berada pada karakteristik tidak berminat/tertarik pada alam. Karakteristik distress spiritual berdasarkan aspek hubungan dengan Tuhan paling banyak berada pada karakteristik ketidakmampuan untuk introspeksi diri dan merasakan penderitaan

Hasil penelitian yang dilakukan Hulu \& Siregar (2018) menunjukkan bahwa secara signifikan strategi koping religius memiliki hubungan dengan penyesuaian diri pada pasien HIV/AIDS di RSUD Gunungsitoli dengan nilai korelasi 0.883 .

Hasil penelitian ini menunjukkan bahwa metode yang paling menggambarkan diri ODHA adalah religius convertion yaitu kembali kepada agama untuk melakukan perubahan besar dalam hidup setelah mengetahui menderita penyakit dengan rata-rata skor metoda religius convertion yaitu 3.34 dan pola religius coping yang lebih menggambarkan diri ODHA adalah religius coping negatif kuat dengan rata-rata skor 3.11 .

\section{SIMPULAN}

Perlunya dukungan dan dorongan penderita HIV/AIDS dalam meningkatkan koping yang adaptif, sehingga dapat mengelola penyakit yang dialaminya.

\section{SARAN}

\section{Saran Teoritis}

Diharapkan dapat dijadikan sebagai gambaran dalam pengembangan intervensi keperawatan khususnya yang berhubungan dengangan gambaran koping religus penderita HIV/AIDS untuk dapat mengelola koping penderita dengan lebih baik.

\section{Saran Praktik \\ Bagi Tempat Penelitian}

Kepada kelompok penderita HIV/AIDS di wilayah Kabupaten Temanggung dalam menghadapi penyakit yang diderita agar dapat meningkatkan koping religus agar hidup jadi lebih baik dan sehat.

\section{Bagi Peneliti Selanjutnya}

Kepada peneliti lain diharapkan dapat melanjutkan penelitian dengan menambahkan variable penelitian lain pada kelompok penderita HIV/AIDS . 


\section{DAFTAR PUSTAKA}

Aisyah, P. S., Widianti, A. T., \& Lusiani, E. (2020). Koping Religius Remaja ODHA di Kota Bandung. Jurnal Pendidikan Keperawatan Indonesia, 6(1), 37-44. DOI: 10.17509/jpki.v6i1.21111

Anggraini., \& Suci, B. D. (2014). Religious Coping dengan Stres pada Mahasiswa. Jurnal Psikologi: Universitas Muhammadiyah Malang, 02(01)

Chaudoir, S. R., Fisher, J. D., \& Simoni, J. M. (2011). Understanding HIV Disclosure: A Review and Application of the Sisclosure Processes Model. Social Science \& Medicine, 72(10), 1618-1629

Hidayah, N. (2014). Efektivitas Group Positive Psychotherapy untuk Meningkatkan Kesejahteraan Psikologis pada Orang Dengan HIVI AIDS (ODHA). Universitas Muhammadiyah Surakarta

Hulu, I. S. A., \& Siregar, A. R (2018). Hubungan Strategi Koping Religius dengan Penyesuaian Diri pada Pasien HIV / AIDS di RSUD Gunungsitoli. Universitas Sumatera Utara

Indriani, S. D., \& Fauziah, N. (2017). Karena Hidup Harus Terus Berjalan (Sebuah Studi Fenomenologi Kehidupan Orang dengan HIV/AIDS). Jurnal Empati, 6(1), 385-395

Kementerian Kesehatan RI. (2017). Profil Kesehatan Indonesia Tahun 2017

Khoiroh, Q. (2013). Hubungan Strategi Coping dengan Tingkat Premenstrual Syndrome pada Mahasiswi Fakultas Psikologi Universitas Islam Negeri Maulana Malik Ibrahim Malang. Universitas Islam Negeri Maulana Malik Ibrahim Malang

Krisdayanti, E., \& Hutasoit, J. I. (2019). Pengaruh Coping Strategies terhadap Kesehatan Mental dan Kualitas Hidup Penderita HIV?AIDS Positif. Jurnal Ilmu Keperawatan Jiwa, 2(3), 179-184

Lubis, L, Sarumpaet, S., M., \& Ismayadi, I. (2016). Hubungan Stigma Depresi dan Kelelahan dengan Kualitas Hidup Pasien dengan HIV/AIDS di Klinik Veteran Medan. Idea Nursing Journal, 7(1)

Muslimah, A. I. (2013). Tingkat Kecemasan dan Strategi Koping Religius terhadap Penyesuaian Diri pada Pasien Hiv/Aids Klinik VCT RSUD Kota Bekasi. Jurnal Soul: Universitas Islam Bekasi, 6(2)

Norcini, P. A. (2015). Illness Perceptions and Coping Strategies among Individuals Diagnosed with HIV. Journal of Behavioral Medicine, 38(4), 620-631. DOI: 10.1007/s10865-015-9639-0

Padila, P. (2012). Buku Ajar Keperawatan Medikal Bedah. Yogyakarta: Nuha Medika

Rouleau, G., Côté, J., \& Cara, C. (2012). Disclosure Experience in a Convenience Sample of Quebec-Born Women Living with HIV: A Phenomenological Study. BMC Women's Health, 12(37), 1-11. DOI:10.1186/1472-6874-12-37

Surahma, W. (2012). Konsep Diri dan Masalah yang Dialami Orang Terinfeksi Hiv/Aids. Jurnal Ilmiah Konseling, 1(1)

Tanjung, D. M., \& Devi, R. (2016). Karakteristik Distress Spiritual pada Orang dengan HIV/AIDS (ODHA) di RSUP Haji Adam Malik Medan. Universitas Sumatera Utara

Trevino, K.M., Pargament, K.I., Cotton, S., Leonard, A.C., Hahn, J., CapriniFaigin, C.A., \& Tsevat, J. (2010). Religious Coping Outcomes in Patients with HIV/AIDS: Cross-sectional and Longitudinal Findings. AIDS and Behaviour, 4(2), 379-389 
Widyarsono, S. (2013). Hubungan antara Depresi dengan Kualitas Hidup Aspek Sosial pada Orang Dengan Hiv/Aids (Odha) (Studi Korelasi terhadap Penderita Hiv/Aids di Rumah Cemara Bandung). Universitas Pendidikan Indonesia

World Health Organization. (2016). Progress Report on HIV in the WHO South-East Asia Region [Internet]. World Health Organization. Available from: http://www.searo.who.int/entity/hiv/data/pr-hiv-sear.pdf?ua=1_ 